\title{
TIPOLOGI NUSANTARA GREEN ARCHITECTURE Dalam Rangka Konservasi Dan Pengembangan Arsitektur Nusantara Bagi Perbaikan Kualitas Lingkungan Binaan
}

\author{
Galih W. Pangarsa, Ema Y. Titisari, Abraham M. Ridjal, dan Jenny Ernawati
}

Jurusan Arsitektur/Fakultas Teknik Universitas Brawijaya

Alamat email penulis : ema.yunita@gmail.com

\section{ABSTRAK}

Pada penelitian ini, Arsitektur Nusantara dianalisis dengan pendekatan tipologis untuk memahami dinamika budayanya. Upaya ini merupakan langkah awal untuk memahami dan merekontekstualisasikan nilai-nilai, filosofi, dan konsep desain yang terkandung dalam Arsitektur Nusantara. Mengingat kejamakan dan kemajemukannya, maka pendekatan tipologi melalui pendekatan budaya dipandang sebagai metode yang paling tepat. Lingkup penelitian disesuaikan dengan etnografi arsitektur nusantara, yaitu diklasifikasikan menurut pulau Jawa, Sumatra, Kalimantan, Sulawesi, dan Papua. Untuk bagian ini penelitian difokuskan pada wilayah Jawa Timur. Hasil studi ini menemukan bahwa perkembangan arsitektur nusantara dapat diklasifikasikan menurut lima kategori budaya yaitu: keperkasaan masyarakat megalitik, kewaspadaan masyarakat pelestari hutan, ketekunan masyarakat tani pedalaman, keterbukaan masyarakat pesisir, dan dinamika masyarakat industri. Untuk kasus wilayah Jawa Timur, dari data yang telah dihimpun, tipologi arsitektur Nusantara yang dapat diidentifikasi adalah ketekunan masyarakat tani pedalaman, keterbukaan masyarakat pesisir, dan dinamika masyarakat industri. Kegiatan penelitian ini dapat dilanjutkan secara bersama-sama (partisipatif) sehingga dapat disusun data base Arsitektur yang dapat dimanfaatkan untuk penelitian-penelitian lainnya.

Kata kunci: tipologi, Arsitektur Nusantara

\section{Pendahuluan}

Arsitektur Nusantara memiliki kandungan keilmuan green-architecture, yang selaras antara manusia dan alam, didasari oleh prinsip ke-Tuhanan. Terbukti teknologi 'tradisional' mampu mengantisipasi permasalahan gempa, banjir, iklim, gangguan binatang buas, dan lain-lain. Konsep green architecture bagi Indonesia seyogyanya dikembangkan dari keilmuan arsitektur Nusantara, bukan keilmuan arsitektur Eropa atau Amerika sebagaimana yang sudah dan sedang terjadi saat ini. Konservasi Arsitektur Nusantara sudah waktunya meninggalkan sisi romantikanya, tak lagi sekedar mengawetkan, tetapi berupaya menggali kandungan keilmuan dari artefak (obyek konservasi) untuk dikembangkan melalui kreativitas dan inovasi sehingga dapat dimanfaatkan untuk kehidupan di masa kini.

Penelitian dan pengembangan Arsitektur Nusantara yang tepat guna dan terpadu perlu segera dilaksanakan. Penyusunan tipologi ini merupakan upaya untuk mensinergikan pengembangan keilmuan sehingga dapat lebih terpadu dan mendapatkan hasil yang optimal serta tepat guna. Percepatan pembangunan yang mengatas-namakan modernisasi seringkali mengabaikan bahkan menindas arsitektur lokal Nusantara, sehingga pelajaran penting yang terkadung di dalamnya ikut terkikis. Permasalahannya, tidak mudah menyusun database Arsitektur Nusantara karena kejamakan dan kemajemukannya. Maka, untuk mempermudah kajian-kajian Arsitektur Nusantara dan penyusunan database-nya diperlukan studi mengenai tipologi. 
Studi ini nantinya akan menghasilkan klasifikasi dan identifikasi Arsitektur Nusantara sesuai dengan kebutuhan dan tujuan penelitian. Studi ini dapat dimanfaatkan oleh para ilmuwan, praktisi, maupun masyarakat luas. Hasil studi ini juga sangat mungkin dimanfaatkan oleh bidang studi lain di luar arsitektur.

\section{Bahan dan Metode}

\subsection{Konsep Green Architecture Pada Arsitektur Nusantara}

Arsitektur Nusantara selalu memegang teguh kaidah-kaidah kehidupan bersama. Arsitektur Nusantara menempatkan dirinya sebagai bagian dari lingkungannya, baik lingkungan alam maupun lingkungan sosial (manusia). Manusia Nusantara memaknai 'rumah' bukan hanya pada bangunan yang dihuninya saja tetapi juga lingkungan sekitar di luar bangunan tempat tinggalnya. Karena itu, pengelolaan lingkungan akan meliputi wilayah yang lebih luas dari sekedar bangunan tempat tinggalnya saja. Arsitektur Nusantara terbukti mampu mengantisipasi permasalahan-permasalahan lingkungan, mulai dari kenyamanan termal, curah hujan yang, tinggi, gempa bumi, banjir, dan sebagainya. Dari aspek pengelolaan limbah, arsitektur Nusantara menunjukkan visibiltas proses alamiah yang siklis. Arsitektur Nusantara juga peka terhadap lingkungan sosial. Arsitekturnya menunjukkan tersedianya ruang bersama sebagai wadah kehidupan sosial mereka.

Karakter utama Arsitektur Nusantara yang hidup bersama dengan lingkungan alam dan lingkungan sosial (manusia) itulah yang membedakannya dengan arsitektur manca (di luar Arsitektur Nusantara) yang individual. Prinsip utama dalam kehidupan Arsitektur Nusantara adalah kasih-sayang dan kepemurahan, dalam bentuk saling memberi, kerjasama (gotong-royong), dan saling menghargai. Prinsip-prinsip inilah yang mampu menjadi jaminan bagi terwujudnya sustainable architecture.

\subsection{Tipologi: Teknik dan Metode Klasifikasi dan Identifikasi Data}

Menurut beberapa kamus (Merriam-Webster Dictionary, Wikipedia, dan Free Online Dictionary), tipologi adalah studi tentang tipe untuk membuat klasifikasiklasifikasi yang didasarkan pada kesamaan karakter obyek. Tipologi sendiri berasal dari bahasa Yunani, yaitu typos (pengelompokan) dan logos (ilmu). Dalam arsitektur dan planologi, tipologi merupakan klasifikasi atau taksonomi karakteristik (fisik) pada bangunan dan tempat-tempat di perkotaan menurut kategori-kategori tertentu, seperti intensitas pembangunannya (dari alamiah, rural hingga urban yang padat), tingkat formalitas (bentuk), dan karakter pemikiran (tradisional, modern). Tipologi dapat dilakukan apabila obyek yang diteliti memiliki kesamaan sifat atau ciri-ciri (Loekito, 1994). Habraken (1988) menyusun tipologi arsitektur menurut sistem spasial (pola ruang, orientasi, hirarki); sistem fisik dan kualitas figural (wujud fisik, bahan/material, dan pembatas ruang); dan sistem stilistik (atap, kolom, bukaan, dan ornamen).

Caniggia dan Maffei (2001), menyatakan bahwa tipe (arsitektur) muncul karena adanya suatu proses logis yang membentuk kesadaran mengenai suatu tipe tertentu. Awalnya pengelompokannya disusun dan dinamakan menurut kesepakatan bersama (Habraken, 1988), tetapi pada proses selanjutnya, seseorang akan dengan mudah mendeskripsikan dan menjelaskan tipe tersebut, bahkan mengenali dan mengelompokkan obyek lain yang memiliki karakter sama ke dalam tipe-tipe tersebut. Caniggia dan Meffei (2001) menyebutnya sebagai kognisi spontan, yang akan segera muncul begitu tipe arsitektur tersebut dinyatakan. Tipe ini bisa terkait dengan aspek fungsi, langgam atau stilistika, periode, latar historis, karakter pemilik bangunan, kemampuan tukang, dan sebagainya. Quatremere de Quincy (dalam Leupen, 1993) 
menyebutnya sebagai model. Durand menyusun tipologi menurut beberapa kategori untuk dijadikan model desain bangunan sejenis.

Kajian tipologi dalam arsitektur juga dapat dilakukan berdasarkan karakter pemikirannya, misalnya arsitektur tradisional (untuk menyebut arsitektur yang dibuat di masa lalu oleh masyarakat kebanyakan secara turun temurun) dan arsitektur modern. Arsitektur tradisional seringkali diikuti oleh etnis pendukung arsitektur tersebut, misalnya arsitektur tradisional Jawa, arsitektur tradisional Betawi, arsitektur tradisional Toraja, dsb. Kelemahannya, 'ikon' bagi masing-masing tipe (etnis) tidak selalu mewakili kelompok etnis yang dimaksud. Penyederhanaan yang dilakukan oleh kajian tipologi semacam ini ternyata berpotensi pada tenggelamnya arsitektur lokal selain yang menjadi ikon.

Kesulitan terbesar menyusun tipologi arsitektur Nusantara adalah karena kejamakan dan kemajemukannya. Diperlukan kejelian dan kehati-hatian dalam menentukan jenis tipologinya sehingga tujuan yang dimaksud dapat tercapai.

Tahap-tahap dalam penelitian tipologi ini adalah:

1. Pengumpulan data-data

2. Identifikasi data sesuai dengan karakteristik dan ciri-cirinya

3. Menetapkan kategori-kategori sesuai dengan tujuan penelitian

4. Menyusun dan mengorganisasi data sesuai klasifikasinya

\section{Hasil dan Pembahasan}

Disadari bahwa teori-teori tipologi yang selama ini dipakai dalam penelitian maupun desain arsitektur sebagaimana dijelaskan di atas, sifatnya masih sangat parsial. Beberapa pendekatan yang telah dilakukan dalam studi tipologi arsitektur antara lain:

1. Pendekatan Etnografi. Dalam hal ini, etnis bisa berangkat dari asal manusia yang terlibat dengan arsitektur tersebut, asal arsitekturnya, atau bahasa yang berkembang di lingkungan arsitektur tersebut.

2. Pendekatan sosiologis/lifestyle, terutama menyangkut ciri utama masyarakat yang terlibat dengan arsitektur tertentu.

3. Aspek Geografi

4. Aspek sejarah

5. Perkembangan peradaban manusia dalam berhuni

6. Aspek rupa-arsitektur

Hendaknya pendekatan tipologis arsitektur Nusantara mampu memunculkan identitas yang jelas untuk dapat dikembangkan menjadi identitas Arsitektur Nusantara yang mempersatukan, bukan memecah-belah etnis, atau melakukan penyederhanaan yang justru menenggelamkan yang lainnya. Identitas tersebut diharapkan mampu menjadi salah satu landasan atau pijakan yang kuat dalam mengembangkan arsitektur kita menjadi lebih baik dan tidak menutup diri pada perubahan dan perkembangan.

Atas dasar pemikiran tersebut, maka penelitian ini menggolongkan atau mengelompokkan Arsitektur Nusantara dalam kategori yang didasarkan pada strategi kebudayaan, yaitu:

\section{Keperkasaan Masyarakat Megalit;}

Melanjutkan sifat-sifat dasar masyarakat mengalit yang selama ini dianggap telah punah, tetapi penerusnya masih memiliki tradisi yang dipegang teguh. Ciri ini hanya tertinggal jejak-jejak tipisnya di beberapa tempat seperti Batak, Sumba atau Toraja. Warisan keperkasaan mengolah batu-batu besar tampak pada arsitekturnya.

\section{Kewaspadaan Pelestari Lingkungan Hutan;}

Kepekaan dalam mengenali dan menjaga kondisi alam di sekitar hunian manusia telah menjadikan masyarakat pelestari hutan waspada dalam mengelola alamnya. 
Fenomena ini sekarang tinggal terwakili oleh beberapa "artefak" saja, misalnya Mentawai atau Papua.

3. Ketekunan Masyarakat Tani Pedalaman;

Kebersamaan dan kejelian dari masyarakat tani pedalaman telah banyak menelurkan norma dan kebudayaan yang menjaga keharmonisan antara manusia, alam dan lingkungan binaannya. Sebagian besar dari arsitektur rakyat Nusantara adalah dari kelompok masyarakat tani pedalaman dan masyarakat tani pesisir pantai dengan ciri "ketekunan mengolah tanah pertanian".

4. Keterbukaan Masyarakat Pesisir

Kondisi alam dan kebutuhan dalam berhuni membentuk masyarakat pesisir menjadi lebih terbuka dalam menata ruangnya. Pendeknya ruang transisi yang mereka bangun seakan menjadikan ruang bersama adalah salah satu cara perlingdungan diri terhadap keberadaan manusia di dalam arsitekturnya. Delha Rote dan Banjar adalah contohnya.

\section{Kelenturan Masyarakat Dagang, Industri dan Informasi}

Arsitektur rakyatnya terkena dampak langsung dari peradaban industri yang mengimbas dari kota-kota besar ke daerah perdesaan di sekitarnya

Contoh klasifikasi data hasil penyusunan tipologi dapat dilihat dalam tabel-tabel pada lampiran.

\section{Kesimpulan}

Hasil yang dapat disimpulkan dari penelitian ini adalah:

\section{Penyusunan Tipologi Mengikuti Tujuan Penjelasan}

Perlu ditegaskan bahwa secara metodologis, tidak ada satu pun pendekatan tipologi yang dapat dijadikan "master key". Bagaimana sesorang membuat klasifikasi terhadap fenomena (yang esensinya majemuk), tergantung dari apa yang hendak dijelaskannya.

2. Tipologi Arsitektur Nusantara disusun menurut Perkembangan Peradaban

Merupakan upaya untuk menjelaskan perkembangan arsitektur Nusantara dalam sumbu historisitas-sinkronik peradaban fisik dan sekaligus ciri paling kuat dari karakter masyarakat yang mewujudkannya, sebagai berikut:

- keperkasaan Masyarakat Megalit;

- kewaspadaan Pelestari Lingkungan Hutan;

- ketekunan Masyarakat Tani Pedalaman;

- keterbukaan Masyarakat Pesisir

- kelenturan Masyarakat Dagang, Industri dan Informasi

\section{Tipologi Arsitektur sebagai Bagian dari Politik Kebudayaan}

Tipologi menurut Perkembangan Peradaban ini bertujuan untuk memberi pemahaman, bahwa dari waktu ke waktu peradaban arsitektur di Nusantara senantiasa berubah-ingsut. Sitem fisiknya boleh berubah, namun nilai-nilai luhur yang masih dapat ditemukan artefak arsitekturnya, seyogyanya dilestarikan. Dengan demikian Indonesia mempunyai bangunan kepribadian bangsa (character dan nation building) yang kokoh - keperkasaan, kewaspadaan, ketekunan, keterbukaan, dan kelenturan-- di tengah-tengah masyarakat global yang mengalami percepatan dinamika peradaban yang sangat dan makin tinggi. 


\section{Ucapan Terima Kasih}

1. Fakultas Teknik Universitas Brawijaya dan BPP FT-UB yang telah memfasilitasi kegiatan penelitian ini.

2. Jurusan Arsitektur FT-UB

3. Rekan-rekan staf pengajar dan mahasiswa yang ikut andil dalam penelitian ini

\section{Daftar Pustaka}

Cowan, Stuart and van de Ryn, Sims. 1996. Ecological Design. USA: Island Press

Hui, Sam C. M. 1996 (updated 2002). Sustainable Architecture. http://www.arch.hku.hk/research/beer/sustain.htm. Didownload November 2011.

Leupen, Bernard, et al. 1993. Design and Analysis. Rotterdam: Otto Publication

Loekito, J. 1994. Studi Tentang Tipologi Tampak Rumah Tinggal di Kampung Surabaya pada Periode Sebelum Tahun 1942. Laporan Penelitian. Tidak dipublikasikan. Surabaya: Jurusan Teknik Arsitektur Universitas Kristen Petra

Loekito, J. 1994. Studi Tentang Tipologi Tampak Rumah Tinggal di Kampung Surabaya pada Periode Sebelum Tahun 1942. Laporan Penelitian. Tidak dipublikasikan. Surabaya: Jurusan Teknik Arsitektur Universitas Kristen Petra,

Maulidia, Femmy. 2010. Tipologi Ornamen Bangunan Kolonial di Kota Malang. Skripsi. Malang: Jurusan Arsitektur Fakultas Teknik Universitas Brawijaya. Unpublished

Morgan, Morris Hicky. 1960. Vitruvius, The Ten Books on Architectur. New York: Dover Publications

Noor Mohammad, Bani. 2005. Model Pelestarian Berbasis Teknologi Informasi. puslit.petra.ac.id/journals/pdf.php?PublishedID=ARS04320201

Nugroho,Bambang Dwi. 2010. Ornamen Bangunan Stasiun Kereta Api Jalur SurabayaMalang. Skripsi. Malang: Jurusan Arsitektur Fakultas Teknik Universitas Brawijaya. unpublished

Nuswantara, Glagah. 2012-03-14. Membongkar Konsep Sustainability. www.4archiculture.net. Didownload Agustus 2012

Oktaviani, Bernadetta. 2010. Ornamen Bangunan Rumah Tinggal Kampung Laweyan Surakarta. Skripsi. Malang: Jurusan Arsitektur Fakultas Teknik Universitas Brawijaya. Unpublished

Pangarsa, Galih W.P. 2007. Merah Putih Arsitektur Nusantara. Yogyakarta: Andi Offset

Papanek, 1972. The Green Imperative: Ecology and Ethics in Design and Architecture. USA: Thames and Hudson

Vale, Brenda and Vale, Robert. 1992. Green Architecture: Design for an Energy-Conscious Future. Bulfinch Press Little Brown and Company

Williams, Daniel E. 2007. Sustainable Design: Ecology, Architecture and Planning. USA: John Willey and Sons

Habraken, N. John. 1988. Type as Social Agreement. Asian Congress of Architect. Korea: Seoul

Habraken, N.John. 1996. Tools of The Trade, Thematic Aspects of Designing.

Caniggia, Gianfranco \& Maffei, Gian Luigi. 2001. Architectural Composition and Building Typology. Alinea Editrice 


\section{LAMPIRAN}

Tabel 1. Pengelompokan Arsitektur berdasarkan aspek amatan Tipologi

\begin{tabular}{|c|c|c|c|c|c|c|}
\hline & $\begin{array}{l}\text { Aspek } \\
\text { Etnis }\end{array}$ & $\begin{array}{l}\text { Aspek } \\
\text { Sosiologis }\end{array}$ & $\begin{array}{l}\text { Aspek } \\
\text { Geografis }\end{array}$ & $\begin{array}{l}\text { Aspek } \\
\text { Sejarah }\end{array}$ & $\begin{array}{l}\text { Proses ke- } \\
\text { kota-an }\end{array}$ & $\begin{array}{l}\text { Arsitektura } \\
\text { l }\end{array}$ \\
\hline & $\begin{array}{l}\text { Bahasa asal, } \\
\text { bahasa } \\
\text { yang } \\
\text { berkembang } \\
\text {, asal } \\
\text { manusia, } \\
\text { asal } \\
\text { arsitektur, } \\
\text { gineakologi }\end{array}$ & $\begin{array}{l}\text { Lifestyle, ciri } \\
\text { utama } \\
\text { masyarakat, } \\
\text { pekerjaan, }\end{array}$ & $\begin{array}{l}\text { Kondisi } \\
\text { alam, } \\
\text { klimatologi, } \\
\text { posisi } \\
\text { geografis }\end{array}$ & $\begin{array}{l}\text { Asal usul } \\
\text { arsitektur, } \\
\text { asal usul } \\
\text { masyarakat, } \\
\text { asal usul } \\
\text { geografis, } \\
\text { kesejarahan } \\
\text { peradaban, }\end{array}$ & $\begin{array}{l}\text { Kondisi desa } \\
\text { dan kota, } \\
\text { perkembanga } \\
n \text { kota dan } \\
\text { arsitekturnya, } \\
\text { perkembanga } \\
n \text { lifestyle } \\
\text { dengan } \\
\text { arsitektur, }\end{array}$ & $\begin{array}{l}\text { Ruang, } \\
\text { material, } \\
\text { konstruksi, } \\
\text { ornamen, } \\
\text { pola hunian, } \\
\text { detail } \\
\text { arsitektur, }\end{array}$ \\
\hline $\begin{array}{l}\text { Arsitektur } \\
\text { Madura }\end{array}$ & $\begin{array}{c}\text { Masyarakat } \\
\text { aseli }\end{array}$ & Pertanian & $\begin{array}{c}\text { Kawasan } \\
\text { persawahan } \\
\text {, ladang }\end{array}$ & Agraris & Peri urban & $\begin{array}{l}\text { Identitas } \\
\text { agraris }\end{array}$ \\
\hline $\begin{array}{l}\text { Arsitektur } \\
\text { Buring, } \\
\text { Malang }\end{array}$ & $\begin{array}{c}\text { Masyarakat } \\
\text { migran }\end{array}$ & $\begin{array}{c}\text { Pertanian, } \\
\text { perladangan }\end{array}$ & $\begin{array}{c}\text { Kawasan } \\
\text { persawahan }\end{array}$ & Agraris & Peri urban & $\begin{array}{c}\text { Identitas } \\
\text { agraris }\end{array}$ \\
\hline $\begin{array}{l}\text { Arsitektur } \\
\text { Sukowono, } \\
\text { Jember }\end{array}$ & $\begin{array}{c}\text { Masyarakat } \\
\text { migran }\end{array}$ & $\begin{array}{c}\text { Pertanian, } \\
\text { perladangan }\end{array}$ & $\begin{array}{c}\text { Kawasan } \\
\text { persawahan }\end{array}$ & Agraris & Peri urban & $\begin{array}{l}\text { Identitas } \\
\text { agraris }\end{array}$ \\
\hline $\begin{array}{l}\text { Arsitektur } \\
\text { Semedusari } \\
\text { Pasuruan }\end{array}$ & $\begin{array}{c}\text { Masyarakat } \\
\text { migran }\end{array}$ & Nelayan & $\begin{array}{l}\text { Pesisir } \\
\text { Pantai }\end{array}$ & Agraris & Peri urban & $\begin{array}{c}\text { Identitas } \\
\text { agraris } \\
\text { pesisir }\end{array}$ \\
\hline $\begin{array}{l}\text { Arsitektur } \\
\text { Tulungagun } \\
\text { g }\end{array}$ & $\begin{array}{c}\text { Masyarakat } \\
\text { aseli }\end{array}$ & Pertanian & $\begin{array}{c}\text { Kawasan } \\
\text { persawahan }\end{array}$ & Agraris & Peri urban & $\begin{array}{l}\text { Identitas } \\
\text { agraris }\end{array}$ \\
\hline $\begin{array}{l}\text { Arsitektur } \\
\text { Bendosari }\end{array}$ & $\begin{array}{c}\text { Masyarakat } \\
\text { aseli }\end{array}$ & Pertanian & $\begin{array}{l}\text { Kawasan } \\
\text { persawahan }\end{array}$ & Agraris & Peri urban & $\begin{array}{c}\text { Identitas } \\
\text { agraris }\end{array}$ \\
\hline $\begin{array}{l}\text { Arsitektur } \\
\text { Donomulyo }\end{array}$ & $\begin{array}{c}\text { Masyarakat } \\
\text { aseli }\end{array}$ & Pertanian & $\begin{array}{l}\text { Kawasan } \\
\text { persawahan }\end{array}$ & Agraris & Peri urban & $\begin{array}{c}\text { Identitas } \\
\text { agraris }\end{array}$ \\
\hline $\begin{array}{l}\text { Arsitektur } \\
\text { Osing }\end{array}$ & $\begin{array}{c}\text { Masyarakat } \\
\text { aseli }\end{array}$ & Pertanian & $\begin{array}{c}\text { Kawasan } \\
\text { persawahan }\end{array}$ & Agraris & Peri urban & $\begin{array}{c}\text { Identitas } \\
\text { agraris }\end{array}$ \\
\hline $\begin{array}{l}\text { Arsitektur } \\
\text { Parsehan } \\
\text { Probolinggo }\end{array}$ & $\begin{array}{c}\text { Masyarakat } \\
\text { migran }\end{array}$ & Nelayan & $\begin{array}{l}\text { Pesisir } \\
\text { pantai }\end{array}$ & $\begin{array}{c}\text { Agraris } \\
\text { pesisir }\end{array}$ & Peri urban & $\begin{array}{c}\text { Identitas } \\
\text { agraris } \\
\text { pesisir }\end{array}$ \\
\hline $\begin{array}{l}\text { Arsitektur } \\
\text { Kampung } \\
\text { Kemasan } \\
\text { Gresik }\end{array}$ & $\begin{array}{c}\text { Masyarakat } \\
\text { campuran } \\
\text { (migran dan } \\
\text { aseli) }\end{array}$ & Pedagang & $\begin{array}{l}\text { Pesisir } \\
\text { pantai }\end{array}$ & $\begin{array}{c}\text { Perdaganga } \\
n \text { dan } \\
\text { Industri }\end{array}$ & Urban & $\begin{array}{l}\text { Identitas } \\
\text { pesisir dan } \\
\text { industri }\end{array}$ \\
\hline $\begin{array}{l}\text { Arsitektur } \\
\text { Trowulan } \\
\end{array}$ & $\begin{array}{c}\text { Masyarakat } \\
\text { aseli }\end{array}$ & Pertanian & $\begin{array}{c}\text { Kawasan } \\
\text { persawahan }\end{array}$ & Agraris & Peri urban & $\begin{array}{c}\text { Identitas } \\
\text { agraris }\end{array}$ \\
\hline $\begin{array}{l}\text { Arsitektur } \\
\text { Kebon } \\
\text { Agung I }\end{array}$ & $\begin{array}{c}\text { Masyarakat } \\
\text { migran }\end{array}$ & $\begin{array}{c}\text { Industri, } \\
\text { perdaganga } \\
n\end{array}$ & $\begin{array}{l}\text { Kawasan } \\
\text { Industri }\end{array}$ & Industri & Urban & $\begin{array}{l}\text { Identitas } \\
\text { Industri }\end{array}$ \\
\hline $\begin{array}{l}\text { Arsitektur } \\
\text { Kebon } \\
\text { Agung II }\end{array}$ & $\begin{array}{c}\text { Masyarakat } \\
\text { aseli }\end{array}$ & Pertanian & $\begin{array}{c}\text { Kawasan } \\
\text { persawahan }\end{array}$ & $\begin{array}{l}\text { Agraris - } \\
\text { industri }\end{array}$ & Peri urban & $\begin{array}{l}\text { Identitas } \\
\text { agraris }\end{array}$ \\
\hline $\begin{array}{l}\text { Arsitektur } \\
\text { Kedawung } \\
\text { Pasuruan }\end{array}$ & $\begin{array}{c}\text { Masyarakat } \\
\text { aseli }\end{array}$ & Pertanian & $\begin{array}{c}\text { Kawasan } \\
\text { persawahan }\end{array}$ & $\begin{array}{l}\text { Agraris - } \\
\text { industri }\end{array}$ & Peri urban & $\begin{array}{l}\text { Identitas } \\
\text { agraris }\end{array}$ \\
\hline
\end{tabular}


Tabel 2. Pengelompokan berdasarkan Aspek Etnis

\begin{tabular}{|c|c|c|c|c|}
\hline & Gineakologi & Asal masyarakat & Asal bahasa & $\begin{array}{l}\text { Bahasa yang } \\
\text { berkembang }\end{array}$ \\
\hline $\begin{array}{l}\text { Arsitektur } \\
\text { Madura }\end{array}$ & Madura & Madura & Madura & Madura \\
\hline $\begin{array}{l}\text { Arsitektur } \\
\text { Buring, Malang }\end{array}$ & $\begin{array}{l}\text { Mayoritas Madura } \\
\text { dengan Jawa } \\
\text { sebagai minoritas } \\
\end{array}$ & Madura, Jawa & Madura, Jawa & Madura, Jawa \\
\hline $\begin{array}{l}\text { Arsitektur } \\
\text { Sukowono } \\
\text { Jember }\end{array}$ & $\begin{array}{l}\text { Mayoritas Madura } \\
\text { dengan Jawa } \\
\text { sebagai minoritas }\end{array}$ & Madura & Madura, Jawa & Madura, Jawa \\
\hline $\begin{array}{l}\text { Arsitektur } \\
\text { Semedusari } \\
\text { Probolinggo } \\
\end{array}$ & $\begin{array}{l}\text { Mayoritas Madura } \\
\text { dengan Jawa } \\
\text { sebagai minoritas }\end{array}$ & Madura & Madura & Madura \\
\hline $\begin{array}{l}\text { Arsitektur } \\
\text { Tulungagung }\end{array}$ & $\begin{array}{l}\text { Mayoritas Jawa, } \\
\text { pendatang lain } \\
\text { minoritas }\end{array}$ & Jawa & Jawa & Jawa \\
\hline $\begin{array}{l}\text { Arsitektur } \\
\text { Donomulyo } \\
\text { Malang } \\
\end{array}$ & $\begin{array}{c}\text { Mayoritas Jawa, } \\
\text { pendatang lain } \\
\text { minoritas }\end{array}$ & Jawa & Jawa & Jawa \\
\hline $\begin{array}{l}\text { Arsitektur } \\
\text { Bendosari } \\
\text { Malang }\end{array}$ & $\begin{array}{c}\text { Mayoritas Jawa, } \\
\text { pendatang lain } \\
\text { minoritas }\end{array}$ & Jawa & Jawa & Jawa \\
\hline Arsitektur Osing & $\begin{array}{c}\text { Mayoritas } \\
\text { Banyuwangi, } \\
\text { sebagian Jawa, } \\
\text { Madura dan Bali }\end{array}$ & $\begin{array}{c}\text { Banyuwangi, Jawa, } \\
\text { Madura dan Bali }\end{array}$ & $\begin{array}{l}\text { Osing, Jawa, } \\
\text { Madura, Bali }\end{array}$ & $\begin{array}{c}\text { Osing, Jawa, } \\
\text { Bahasa Indonesia }\end{array}$ \\
\hline $\begin{array}{l}\text { Arsitektur } \\
\text { Probolinggo }\end{array}$ & $\begin{array}{l}\text { Mayoritas Jawa } \\
\text { dan Madura, } \\
\text { pendatang lain } \\
\text { minoritas }\end{array}$ & Jawa, Madura & Madura, Jawa & Madura \\
\hline $\begin{array}{l}\text { Arsitektur } \\
\text { Kampung } \\
\text { Kemasan Gresik }\end{array}$ & $\begin{array}{c}\text { Jawa, multi etnis } \\
\text { (Arab, Cina, dll) }\end{array}$ & Jawa, Arab, Cina & Jawa & Jawa \\
\hline $\begin{array}{l}\text { Arsitektur } \\
\text { Trowulan }\end{array}$ & $\begin{array}{c}\text { Mayoritas Jawa, } \\
\text { pendatang lain } \\
\text { minoritas } \\
\end{array}$ & Jawa & Jawa & Jawa \\
\hline $\begin{array}{l}\text { Arsitektur Kebon } \\
\text { Agung I }\end{array}$ & $\begin{array}{l}\text { Mayoritas Jawa, } \\
\text { pendatang lain } \\
\text { minoritas }\end{array}$ & Jawa & Jawa & Jawa \\
\hline $\begin{array}{l}\text { Arsitektur Kebon } \\
\text { Agung II }\end{array}$ & Mayoritas Jawa & $\begin{array}{l}\text { pendatang lain } \\
\text { minoritas }\end{array}$ & Mayoritas Jawa & $\begin{array}{l}\text { pendatang lain } \\
\text { minoritas }\end{array}$ \\
\hline $\begin{array}{l}\text { Arsitektur } \\
\text { Kedawung } \\
\text { Pasuruan }\end{array}$ & Mayoritas Jawa & $\begin{array}{l}\text { pendatang lain } \\
\text { minoritas }\end{array}$ & Mayoritas Jawa & $\begin{array}{l}\text { pendatang lain } \\
\text { minoritas }\end{array}$ \\
\hline
\end{tabular}


Tabel 3 Pengelompokan berdasarkan Aspek Sosiologis

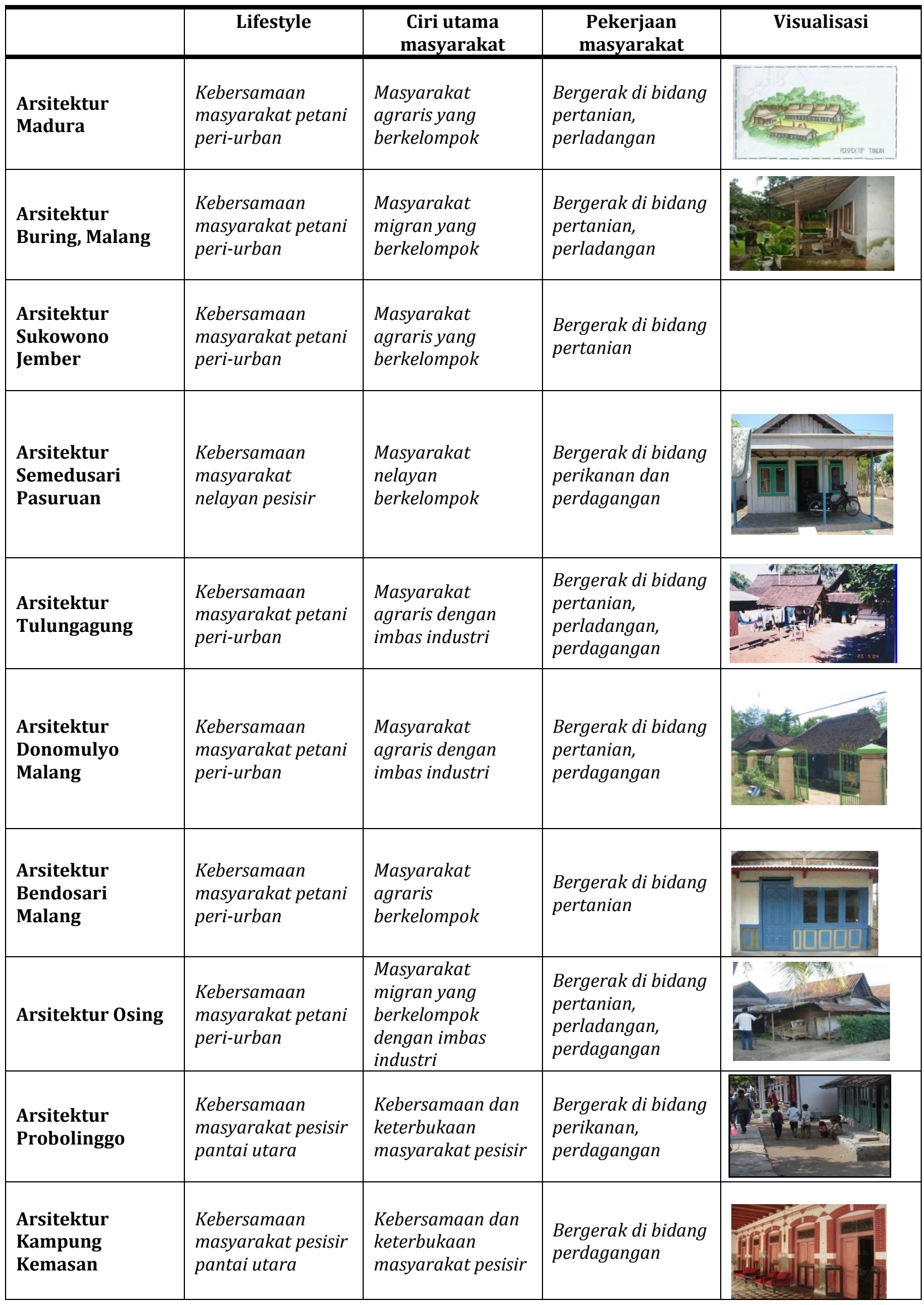




\begin{tabular}{|l|l|l|l|l|}
\hline & & & \\
\hline $\begin{array}{l}\text { Arsitektur } \\
\text { Trowulan }\end{array}$ & $\begin{array}{l}\text { Kebersamaan } \\
\text { masyarakat petani } \\
\text { peri-urban }\end{array}$ & $\begin{array}{l}\text { Masyarakat } \\
\text { migran yang } \\
\text { berkelompok } \\
\text { dengan imbas } \\
\text { industri }\end{array}$ & $\begin{array}{l}\text { Bergerak di bidang } \\
\text { pertanian, } \\
\text { perladangan, } \\
\text { perdagangan }\end{array}$ \\
\hline $\begin{array}{l}\text { Arsitektur Kebon } \\
\text { Agung I }\end{array}$ & $\begin{array}{l}\text { Masyarakat } \\
\text { agraris dengan } \\
\text { dampak } \\
\text { indutrialisasi }\end{array}$ & $\begin{array}{l}\text { Masyarakat } \\
\text { industri }\end{array}$ & $\begin{array}{l}\text { Bergerak di bidang } \\
\text { industri dan } \\
\text { perdagangan }\end{array}$ \\
\hline $\begin{array}{l}\text { Arsitektur Kebon } \\
\text { Agung II }\end{array}$ & $\begin{array}{l}\text { Masyarakat } \\
\text { agraris dengan } \\
\text { dampak } \\
\text { indutrialisasi }\end{array}$ & $\begin{array}{l}\text { Masyarakat } \\
\text { industri-pertanian }\end{array}$ & $\begin{array}{l}\text { Bergerakdi bidang } \\
\text { pertanian }\end{array}$ \\
\hline $\begin{array}{l}\text { Arsitektur } \\
\text { Kedawung } \\
\text { Pasuruan }\end{array}$ & $\begin{array}{l}\text { Masyarakat } \\
\text { agraris dengan } \\
\text { dampak } \\
\text { indutrialisasi }\end{array}$ & $\begin{array}{l}\text { Masyarakat } \\
\text { industri-pertanian }\end{array}$ & $\begin{array}{l}\text { Bergerakdi bidang } \\
\text { pertanian }\end{array}$ \\
\hline
\end{tabular}

Tabel 4. Pengelompokan berdasarkan Aspek Geografis

\begin{tabular}{|c|c|c|c|c|}
\hline & Posisi Geografis & Klimatologis & Kondisi alam & Visualisasi \\
\hline $\begin{array}{l}\text { Arsitektur } \\
\text { Madura }\end{array}$ & $\begin{array}{l}\text { Pulau Madura, } \\
\text { Jawa Timur }\end{array}$ & $\begin{array}{l}\text { Tropis lembab, } \\
\text { dengan } \\
\text { kelembaban } \\
\text { yang cukup } \\
\text { rendah }\end{array}$ & $\begin{array}{l}\text { Kondisi tanah cukup } \\
\text { kering, tidak sebasah } \\
\text { pulau Jawa }\end{array}$ & \\
\hline $\begin{array}{l}\text { Arsitektur } \\
\text { Buring, Malang }\end{array}$ & $\begin{array}{l}\text { Kecamatan Buring, } \\
\text { Keluruhan } \\
\text { Bumiayu, } \\
\text { Kabupaten Malang }\end{array}$ & Tropis lembab & $\begin{array}{l}\text { Daerah pegunungan } \\
\text { yang cukup kering } \\
\text { dengan sumber mata } \\
\text { air yang cukup dalam }\end{array}$ & \\
\hline $\begin{array}{l}\text { Arsitektur } \\
\text { Sukowono } \\
\text { Jember }\end{array}$ & $\begin{array}{l}\text { Kecamatan } \\
\text { Sukowono, Jember }\end{array}$ & Tropis lembab & $\begin{array}{l}\text { Kondisi tanah cukup } \\
\text { subur dengan } \\
\text { kelembaban tinggi }\end{array}$ & \\
\hline $\begin{array}{l}\text { Arsitektur } \\
\text { Semedusari } \\
\text { Pasuruan }\end{array}$ & $\begin{array}{l}\text { Desa Semedusari, } \\
\text { Kecamatan Lekok, } \\
\text { kabupaten } \\
\text { Pasuruan }\end{array}$ & Tropis lembab & Kondisi tanah berpasir & \\
\hline $\begin{array}{l}\text { Arsitektur } \\
\text { Tulungagung }\end{array}$ & $\begin{array}{l}\text { Desa Nglurup, } \\
\text { Kecamatan } \\
\text { Sendang,Kabupaten } \\
\text { Tulungagung }\end{array}$ & Tropis lembab & $\begin{array}{l}\text { Kondisi tanah cukup } \\
\text { subur dengan } \\
\text { kelembaban tinggi }\end{array}$ & \\
\hline
\end{tabular}




\begin{tabular}{|c|c|c|c|c|}
\hline $\begin{array}{l}\text { Arsitektur } \\
\text { Donomulyo } \\
\text { Malang }\end{array}$ & $\begin{array}{l}\text { Kecamatan } \\
\text { Donomulyo } \\
\text { Kabupaten Malang }\end{array}$ & Tropis lembab & $\begin{array}{l}\text { Kondisi tanah cukup } \\
\text { subur dengan } \\
\text { kelembaban tinggi }\end{array}$ & \\
\hline $\begin{array}{l}\text { Arsitektur } \\
\text { Bendosari } \\
\text { Malang }\end{array}$ & $\begin{array}{l}\text { Kecamatan Pujon } \\
\text { Kabupaten Malang }\end{array}$ & Tropis lembab & $\begin{array}{l}\text { Kondisi tanah cukup } \\
\text { subur dengan } \\
\text { kelembaban tinggi }\end{array}$ & \\
\hline Arsitektur Osing & $\begin{array}{l}\text { Desa Kemiren, } \\
\text { Kecamatan } \\
\text { Glagah,Kabupaten } \\
\text { Banyuwangi }\end{array}$ & Tropis lembab & $\begin{array}{l}\text { Kondisi tanah cukup } \\
\text { subur dengan } \\
\text { kelembaban tinggi }\end{array}$ & \\
\hline $\begin{array}{l}\text { Arsitektur } \\
\text { Probolinggo }\end{array}$ & $\begin{array}{l}\text { Dusun Parsehan, } \\
\text { desa Tamansari, } \\
\text { Kecamatan Dringu, } \\
\text { Probolinggo }\end{array}$ & $\begin{array}{l}\text { Tropis lembab, } \\
\text { dengan kondisi } \\
\text { alam pesisir } \\
\text { yang kering }\end{array}$ & $\begin{array}{l}\text { Dominasi pasir } \\
\text { sebagai ciri khas } \\
\text { kawasan pesisir }\end{array}$ & \\
\hline $\begin{array}{l}\text { Arsitektur } \\
\text { Kampung } \\
\text { Kemasan Gresik }\end{array}$ & $\begin{array}{l}\text { Kecamatan Gresik } \\
\text { Kabupaten Gresik }\end{array}$ & $\begin{array}{l}\text { Tropis lembab, } \\
\text { dengan kondisi } \\
\text { alam pesisir } \\
\text { yang kering }\end{array}$ & $\begin{array}{l}\text { Kondisi tanah agak } \\
\text { kering }\end{array}$ & \\
\hline $\begin{array}{l}\text { Arsitektur } \\
\text { Trowulan }\end{array}$ & $\begin{array}{l}\text { Dusun Kedaton, } \\
\text { Desa Sentonorejo, } \\
\text { Trowulan }\end{array}$ & Tropis lembab & $\begin{array}{l}\text { Kondisi tanah cukup } \\
\text { subur dengan } \\
\text { kelembaban tinggi }\end{array}$ & \\
\hline $\begin{array}{l}\text { Arsitektur Kebon } \\
\text { Agung I }\end{array}$ & $\begin{array}{l}\text { Kebonagung, } \\
\text { Malang }\end{array}$ & Tropis lembab & $\begin{array}{l}\text { Kondisi tanah cukup } \\
\text { subur dengan } \\
\text { kelembaban tinggi, } \\
\text { sesuai untuk area } \\
\text { perladangan }\end{array}$ & \\
\hline $\begin{array}{l}\text { Arsitektur Kebon } \\
\text { Agung II }\end{array}$ & $\begin{array}{l}\text { Kebonagung, } \\
\text { Malang }\end{array}$ & Tropis lembab & $\begin{array}{l}\text { Kondisi tanah cukup } \\
\text { subur dengan } \\
\text { kelembaban tinggi, } \\
\text { sesuai untuk area } \\
\text { perladangan }\end{array}$ & \\
\hline $\begin{array}{l}\text { Arsitektur } \\
\text { Kedawung } \\
\text { Pasuruan }\end{array}$ & $\begin{array}{l}\text { Kecamatan } \\
\text { Kedawung, } \\
\text { Kabupaten } \\
\text { Pasuruan }\end{array}$ & Tropis lembab & $\begin{array}{l}\text { Kondisi tanah cukup } \\
\text { subur dengan } \\
\text { kelembaban tinggi, } \\
\text { sesuai untuk area } \\
\text { perladangan }\end{array}$ & \\
\hline
\end{tabular}


Tabel 5 Pengelompokan Berdasarkan Kesejarahan

\begin{tabular}{|c|c|c|c|c|}
\hline & Asal Arsitektur & Asal Masyarakat & Sejarah Geografis & $\begin{array}{l}\text { Sejarah } \\
\text { Peradaban }\end{array}$ \\
\hline $\begin{array}{l}\text { Arsitektur } \\
\text { Madura }\end{array}$ & $\begin{array}{l}\text { Arsitektur yang } \\
\text { tumbuh dari } \\
\text { daerah Madura } \\
\text { sendiri }\end{array}$ & $\begin{array}{l}\text { Masyarakat } \\
\text { Madura sebagai } \\
\text { masyarakat aseli }\end{array}$ & $\begin{array}{l}\text { Kondisi geografis } \\
\text { yang khas turut } \\
\text { mewarnai } \\
\text { arsitektur sebagai } \\
\text { lingkungan binaan } \\
\text { manusia }\end{array}$ & $\begin{array}{l}\text { Proses tumbuhnya } \\
\text { peradaban telah } \\
\text { berlanmgsung } \\
\text { selama beberapa } \\
\text { abad. }\end{array}$ \\
\hline $\begin{array}{l}\text { Arsitektur } \\
\text { Buring, Malang }\end{array}$ & $\begin{array}{l}\text { Merupakan hasil } \\
\text { akulturasi antara } \\
\text { arsitektur Madura } \\
\text { dengan lokal }\end{array}$ & $\begin{array}{l}\text { Kebanyakan } \\
\text { masyarakat } \\
\text { datang dari Pulau } \\
\text { Madura }\end{array}$ & $\begin{array}{l}\text { Kondisi alam di } \\
\text { Buring, Malang } \\
\text { menyerupai alam } \\
\text { Madura sebagai } \\
\text { alam } \\
\text { masyarakatnya }\end{array}$ & $\begin{array}{l}\text { Akulturasi terjadi } \\
\text { dengan adanya } \\
\text { proses penyesuain } \\
\text { masyarakat } \\
\text { dengan lokasi } \\
\text { barunya. }\end{array}$ \\
\hline $\begin{array}{l}\text { Arsitektur } \\
\text { Sukowono, } \\
\text { Jember }\end{array}$ & $\begin{array}{l}\text { Merupakan hasil } \\
\text { akulturasi antara } \\
\text { arsitektur Madura } \\
\text { dengan lokal }\end{array}$ & $\begin{array}{l}\text { Kebanyakan } \\
\text { masyarakat } \\
\text { datang dari Pulau } \\
\text { Madura }\end{array}$ & & $\begin{array}{l}\text { Akulturasi terjadi } \\
\text { dengan adanya } \\
\text { proses penyesuain } \\
\text { masyarakat } \\
\text { dengan lokasi } \\
\text { barunya. }\end{array}$ \\
\hline $\begin{array}{l}\text { Arsitektur } \\
\text { Semedusari, } \\
\text { Pasuruan }\end{array}$ & $\begin{array}{l}\text { Merupakan hasil } \\
\text { akulturasi antara } \\
\text { arsitektur Madura } \\
\text { dengan lokal }\end{array}$ & $\begin{array}{l}\text { Kebanyakan } \\
\text { masyarakat } \\
\text { datang dari Pulau } \\
\text { Madura }\end{array}$ & $\begin{array}{l}\text { Kondisi alam } \\
\text { pesisir menyerupai } \\
\text { alam asal } \\
\text { masyarakatnya }\end{array}$ & $\begin{array}{l}\text { Akulturasi terjadi } \\
\text { dengan adanya } \\
\text { proses penyesuain } \\
\text { masyarakat } \\
\text { dengan lokasi } \\
\text { barunya. }\end{array}$ \\
\hline $\begin{array}{l}\text { Arsitektur } \\
\text { Tulungagung }\end{array}$ & $\begin{array}{l}\text { Arsitektur yang } \\
\text { tumbuh di } \\
\text { kawasan Sendang, } \\
\text { Tulungagung, } \\
\text { meskipun terdapat } \\
\text { pengaruh juga dari } \\
\text { luar Tulungagung }\end{array}$ & $\begin{array}{l}\text { Masyarakat } \\
\text { Tulungagung, } \\
\text { sebagin } \\
\text { masyarakat } \\
\text { pendatang dari } \\
\text { arah Barat dan } \\
\text { sebagian kecil dari } \\
\text { Timur }\end{array}$ & $\begin{array}{l}\text { Kondisi alam } \\
\text { Tulungagung turut } \\
\text { mewarnai } \\
\text { Arsitekturnya. }\end{array}$ & $\begin{array}{l}\text { Proses tumbuhnya } \\
\text { arsitektur telah } \\
\text { ikut juga } \\
\text { mewarnai } \\
\text { peradaban } \\
\text { kawasan } \\
\text { Tulungagung. }\end{array}$ \\
\hline $\begin{array}{l}\text { Arsitektur } \\
\text { Donomulyo } \\
\text { Malang }\end{array}$ & $\begin{array}{l}\text { Arsitektur berakar } \\
\text { dari budaya } \\
\text { Mataraman Jawa } \\
\text { Tengah }\end{array}$ & $\begin{array}{l}\text { Masyarakat } \\
\text { Donomulyo, konon } \\
\text { berasal dari Jawa } \\
\text { Tengah }\end{array}$ & $\begin{array}{l}\text { Kondisi alam turut } \\
\text { mewarnai } \\
\text { Arsitekturnya. }\end{array}$ & $\begin{array}{l}\text { Proses tumbuhnya } \\
\text { arsitektur telah } \\
\text { ikut juga } \\
\text { mewarnai } \\
\text { peradaban } \\
\text { kawasan }\end{array}$ \\
\hline $\begin{array}{l}\text { Arsitektur } \\
\text { Bendosari } \\
\text { Malang }\end{array}$ & $\begin{array}{l}\text { Arsitektur yang } \\
\text { tumbuh dari } \\
\text { Bendosari Malang }\end{array}$ & Masyarakat asli & $\begin{array}{l}\text { Kondisi alam turut } \\
\text { mewarnai } \\
\text { Arsitekturnya. }\end{array}$ & $\begin{array}{l}\text { Proses tumbuhnya } \\
\text { arsitektur telah } \\
\text { ikut juga } \\
\text { mewarnai } \\
\text { peradaban } \\
\text { kawasan }\end{array}$ \\
\hline Arsitektur Osing & $\begin{array}{l}\text { Arsitektur yang } \\
\text { tumbuh dari } \\
\text { daerah Kemiren, } \\
\text { Banyuwangi }\end{array}$ & $\begin{array}{l}\text { Masyarakat } \\
\text { Banyuwangi } \\
\text { sebagai } \\
\text { masyarakat aseli }\end{array}$ & $\begin{array}{l}\text { Kondisi geografis } \\
\text { yang khas turut } \\
\text { mewarnai } \\
\text { arsitektur sebagai } \\
\text { lingkungan binaan } \\
\text { manusia }\end{array}$ & $\begin{array}{l}\text { Proses tumbuhnya } \\
\text { peradaban telah } \\
\text { berlanngsung } \\
\text { selama beberapa } \\
\text { abad. }\end{array}$ \\
\hline
\end{tabular}




\begin{tabular}{|c|c|c|c|c|}
\hline $\begin{array}{l}\text { Arsitektur } \\
\text { Probolinggo }\end{array}$ & $\begin{array}{l}\text { Arsitektur yang } \\
\text { tumbuh di } \\
\text { kawasan Parsehan, } \\
\text { Probolinggo, } \\
\text { meskipun terdapat } \\
\text { pengaruh juga dari } \\
\text { luar Probolinggo }\end{array}$ & $\begin{array}{l}\text { Masyarakat } \\
\text { Probolinggo, } \\
\text { sebagian besar } \\
\text { adalah masyarakt } \\
\text { pendatang }\end{array}$ & $\begin{array}{l}\text { Kondisi alam } \\
\text { Probolingo sebagai } \\
\text { daerah pesisir } \\
\text { turut mewarnai } \\
\text { Arsitekturnya. }\end{array}$ & $\begin{array}{l}\text { Proses tumbuhnya } \\
\text { arsitektur telah } \\
\text { ikut juga } \\
\text { mewarnai } \\
\text { peradaban } \\
\text { kawasan } \\
\text { Probolinggo }\end{array}$ \\
\hline $\begin{array}{l}\text { Arsitektur } \\
\text { Kampung } \\
\text { Kemasan Gresik }\end{array}$ & $\begin{array}{l}\text { Arsitektur yang } \\
\text { tumbuh dari } \\
\text { Kampung } \\
\text { Kemasan, hasil } \\
\text { perpaduan } \\
\text { pengaruh } \\
\text { beberapa budaya }\end{array}$ & $\begin{array}{l}\text { Sebagian } \\
\text { pendatang, multi } \\
\text { etnis }\end{array}$ & $\begin{array}{l}\text { Kondisi alam dan } \\
\text { posisi geografis } \\
\text { memungkinkan } \\
\text { terbentuknya } \\
\text { masyarakat } \\
\text { multietnis yang } \\
\text { mewarnai } \\
\text { arsitekturnya }\end{array}$ & $\begin{array}{l}\text { Akulturasi terjadi } \\
\text { dengan adanya } \\
\text { proses penyesuain } \\
\text { masyarakat } \\
\text { dengan lokasi } \\
\text { barunya. }\end{array}$ \\
\hline $\begin{array}{l}\text { Arsitektur } \\
\text { Trowulan }\end{array}$ & $\begin{array}{l}\text { Arsitektur yang } \\
\text { tumbuh dari } \\
\text { daerah } \\
\text { Sentonorejo, } \\
\text { Trowulan }\end{array}$ & $\begin{array}{l}\text { Masyarakat } \\
\text { Trowulan, } \\
\text { sebagian besar } \\
\text { adalah masyarakt } \\
\text { pendatang }\end{array}$ & $\begin{array}{l}\text { Kondisi alam } \\
\text { Trowulan turut } \\
\text { mewarnai } \\
\text { Arsitekturnya. }\end{array}$ & $\begin{array}{l}\text { Proses tumbuhnya } \\
\text { arsitektur telah } \\
\text { ikut juga } \\
\text { mewarnai } \\
\text { peradaban } \\
\text { kawasan Trowulan }\end{array}$ \\
\hline $\begin{array}{l}\text { Arsitektur Kebon } \\
\text { Agung I }\end{array}$ & $\begin{array}{l}\text { Arsitektur yang } \\
\text { tumbuh sebagai } \\
\text { dampak dari } \\
\text { kawasan industri }\end{array}$ & $\begin{array}{l}\text { Masyarakat } \\
\text { Kebonagung, } \\
\text { sebagian besar } \\
\text { adalah masyarakat } \\
\text { pendatang sebagai } \\
\text { dampak } \\
\text { industrialisasi }\end{array}$ & $\begin{array}{l}\text { Kondisi alam } \\
\text { Kebonagung yang } \\
\text { menjadi magnet } \\
\text { industri pada masa } \\
\text { lalu }\end{array}$ & $\begin{array}{l}\text { Proses tumbuhnya } \\
\text { arsitektur telah } \\
\text { ikut juga } \\
\text { mewarnai } \\
\text { peradaban } \\
\text { kawasan Industri } \\
\text { Gula masa lalu. }\end{array}$ \\
\hline $\begin{array}{l}\text { Arsitektur Kebon } \\
\text { Agung II }\end{array}$ & $\begin{array}{l}\text { Arsitektur tumbuh } \\
\text { dari daerah Kebon } \\
\text { agung, dampak } \\
\text { industri } \\
\text { memperngaruhi } \\
\text { perkembangannya }\end{array}$ & $\begin{array}{l}\text { Masyarakat asli } \\
\text { Desa Sememek } \\
\text { kebon agung }\end{array}$ & $\begin{array}{l}\text { Kondisi alam } \\
\text { mewarnai } \\
\text { arsitekturnya }\end{array}$ & $\begin{array}{l}\text { Proses tumbuhnya } \\
\text { arsitektur telah } \\
\text { ikutjuga } \\
\text { mewarnai } \\
\text { peradaban } \\
\text { kawasan Industri } \\
\text { Gula masa lalu. }\end{array}$ \\
\hline $\begin{array}{l}\text { Arsitektur } \\
\text { Kedawung } \\
\text { pasuruan }\end{array}$ & $\begin{array}{l}\text { Arsitektur tumbuh } \\
\text { dari daerah Kebon } \\
\text { agung, dampak } \\
\text { industri } \\
\text { memperngaruhi } \\
\text { perkembangannya }\end{array}$ & $\begin{array}{l}\text { Masyarakat asli } \\
\text { desa Kedawung }\end{array}$ & $\begin{array}{l}\text { Kondisi alam } \\
\text { mewarnai } \\
\text { arsitekturnya }\end{array}$ & $\begin{array}{l}\text { Proses tumbuhnya } \\
\text { arsitektur telah } \\
\text { ikut juga } \\
\text { mewarnai } \\
\text { peradaban } \\
\text { kawasan Industri } \\
\text { Gula masa lalu. }\end{array}$ \\
\hline
\end{tabular}

Tabel 6 Pengelompokan Berdasarkan Proses ke-Kota-an

\begin{tabular}{|l|l|l|l|l|}
\hline & \multicolumn{1}{|c|}{$\begin{array}{c}\text { Kondisi desa } \\
\text { dan kota }\end{array}$} & $\begin{array}{c}\text { Perkembangan } \\
\text { kota dan } \\
\text { arsitekturnya }\end{array}$ & $\begin{array}{l}\text { Perkembangan } \\
\text { lifestyle dengan } \\
\text { arsitektur }\end{array}$ & Visualisasi \\
\hline $\begin{array}{l}\text { Arsitektur } \\
\text { Madura }\end{array}$ & $\begin{array}{l}\text { Lokasi di } \\
\text { kawasan peri- } \\
\text { urban }\end{array}$ & $\begin{array}{l}\text { Karakter kawasan } \\
\text { yang kuat turut } \\
\text { mewarnai } \\
\text { arsitekturnya }\end{array}$ & $\begin{array}{l}\text { katnya identitas } \\
\text { kawasan hampir } \\
\text { tidak terpengaruh } \\
\text { secara signifikan } \\
\text { dengan } \\
\text { perkembangan } \\
\text { urban }\end{array}$ & \\
\hline
\end{tabular}




\begin{tabular}{|c|c|c|c|c|}
\hline $\begin{array}{l}\text { Arsitektur } \\
\text { Buring, Malang }\end{array}$ & $\begin{array}{l}\text { Lokasi di } \\
\text { kawasan peri- } \\
\text { urban }\end{array}$ & $\begin{array}{l}\text { Perkembangan } \\
\text { kawasan peri- } \\
\text { urban di Malang } \\
\text { turut mendukung } \\
\text { perkembangan } \\
\text { arsitekturnya } \\
\end{array}$ & $\begin{array}{l}\text { Meluasnya } \\
\text { dampak urban } \\
\text { mengurangi } \\
\text { jumlah petani di } \\
\text { kawasan ini }\end{array}$ & $8-$ \\
\hline $\begin{array}{l}\text { Arsitektur } \\
\text { Sukowono, } \\
\text { Jember }\end{array}$ & $\begin{array}{l}\text { Lokasi di } \\
\text { kawasan peri- } \\
\text { urban }\end{array}$ & $\begin{array}{l}\text { Perkembangan } \\
\text { kawasan peri- } \\
\text { urban di Jember } \\
\text { ikut mendukung } \\
\text { perkembangan } \\
\text { arsitekturnya } \\
\end{array}$ & $\begin{array}{l}\text { Meluasnya } \\
\text { dampak urban } \\
\text { mengurangi } \\
\text { jumlah petani di } \\
\text { kawasan ini }\end{array}$ & \\
\hline $\begin{array}{l}\text { Arsitektur } \\
\text { Semedusari, } \\
\text { Pasuruan }\end{array}$ & $\begin{array}{l}\text { Lokasi di } \\
\text { kawasan peri- } \\
\text { urban }\end{array}$ & $\begin{array}{l}\text { Perkembangan } \\
\text { kawasan peri- } \\
\text { urban di Pasuruan } \\
\text { ikut mendukung } \\
\text { perkembangan } \\
\text { arsitekturnya }\end{array}$ & $\begin{array}{l}\text { Meluasnya } \\
\text { dampak urban } \\
\text { mengurangi } \\
\text { jumlah petani di } \\
\text { kawasan ini }\end{array}$ & $\frac{1}{3}-0$ \\
\hline $\begin{array}{l}\text { Arsitektur } \\
\text { Tulungagung }\end{array}$ & $\begin{array}{l}\text { Lokasi di } \\
\text { kawasan peri- } \\
\text { urban }\end{array}$ & $\begin{array}{l}\text { Perkembangan } \\
\text { kawasan peri- } \\
\text { urban di } \\
\text { Tulungagung turut } \\
\text { mendukung } \\
\text { perkembangan } \\
\text { arsitekturnya }\end{array}$ & $\begin{array}{l}\text { Meluasnya } \\
\text { dampak urban } \\
\text { mengurangi } \\
\text { jumlah petani di } \\
\text { kawasan ini }\end{array}$ & \\
\hline $\begin{array}{l}\text { Arsitektur } \\
\text { Donomulyo } \\
\text { Malang }\end{array}$ & $\begin{array}{l}\text { Lokasi di } \\
\text { kawasan peri- } \\
\text { urban }\end{array}$ & $\begin{array}{l}\text { Perkembangan } \\
\text { kawasan peri- } \\
\text { urban di Malang } \\
\text { turut mendukung } \\
\text { perkembangan } \\
\text { arsitekturnya }\end{array}$ & $\begin{array}{l}\text { Meluasnya } \\
\text { dampak urban } \\
\text { mengurangi } \\
\text { jumlah petani di } \\
\text { kawasan ini }\end{array}$ & \\
\hline $\begin{array}{l}\text { Arsitektur } \\
\text { Bendosari } \\
\text { Malang }\end{array}$ & $\begin{array}{l}\text { Lokasi di } \\
\text { kawasan peri- } \\
\text { urban }\end{array}$ & $\begin{array}{l}\text { Perkembangan } \\
\text { kawasan peri- } \\
\text { urban di Malang } \\
\text { dan Batu turut } \\
\text { mendukung } \\
\text { perkembangan } \\
\text { arsitekturnya } \\
\end{array}$ & $\begin{array}{l}\text { Masih didominasi } \\
\text { pertanian, tetapi } \\
\text { sudah mengarah } \\
\text { ke produk jasa } \\
\text { (agrowisata) } \\
\text { akibat pengaruh } \\
\text { kegiatan urban }\end{array}$ & \\
\hline Arsitektur Osing & $\begin{array}{l}\text { Lokasi di } \\
\text { kawasan peri- } \\
\text { urban }\end{array}$ & $\begin{array}{l}\text { Karakter kawasan } \\
\text { yang kuat turut } \\
\text { mewarnai } \\
\text { arsitekturnya }\end{array}$ & $\begin{array}{l}\text { Meluasnya } \\
\text { dampak urban } \\
\text { mengurangi } \\
\text { jumlah petani di } \\
\text { kawasan ini }\end{array}$ & \\
\hline $\begin{array}{l}\text { Arsitektur } \\
\text { Probolinggo }\end{array}$ & $\begin{array}{l}\text { Lokasi di } \\
\text { kawasan peri- } \\
\text { urban }\end{array}$ & $\begin{array}{l}\text { Perkembangan } \\
\text { kawasan peri- } \\
\text { urban di Malang } \\
\text { turut mendukung } \\
\text { perkembangan } \\
\text { arsitekturnya }\end{array}$ & $\begin{array}{l}\text { Meluasnya } \\
\text { dampak urban } \\
\text { mengurangi } \\
\text { jumlah nelayan di } \\
\text { kawasan ini }\end{array}$ & \\
\hline $\begin{array}{l}\text { Arsitektur } \\
\text { Kampung } \\
\text { Kemasan Gresik }\end{array}$ & $\begin{array}{l}\text { Lokasi di } \\
\text { kawasan urban }\end{array}$ & $\begin{array}{l}\text { Perkembangan } \\
\text { kota belum } \\
\text { mengubah } \\
\text { arsitektur khas } \\
\text { Kampung } \\
\text { Kemasan secara } \\
\text { signifikan }\end{array}$ & $\begin{array}{l}\text { Tidak terjadi } \\
\text { perubahan } \\
\text { signifikan terkait } \\
\text { mata pencaharian } \\
\text { masyarakat }\end{array}$ & in \\
\hline
\end{tabular}




\begin{tabular}{|l|l|l|l|}
\hline $\begin{array}{l}\text { Arsitektur } \\
\text { Trowulan }\end{array}$ & $\begin{array}{l}\text { Lokasi di } \\
\text { kawasan peri- } \\
\text { urban }\end{array}$ & $\begin{array}{l}\text { Perkembangan } \\
\text { kawasan peri- } \\
\text { urban di Malang } \\
\text { turut mendukung } \\
\text { perkembangan } \\
\text { arsitekturnya }\end{array}$ & $\begin{array}{l}\text { Meluasnya } \\
\text { dampak urban } \\
\text { mengurangi } \\
\text { jumlah petani di } \\
\text { kawasan ini }\end{array}$ \\
$\begin{array}{l}\text { Arsitektur } \\
\text { Kebon Agung I }\end{array}$ & $\begin{array}{l}\text { Lokasi di } \\
\text { kawasan urban }\end{array}$ & $\begin{array}{l}\text { Karakter kawasan } \\
\text { yang kuat turut } \\
\text { mewarnai } \\
\text { arsitekturnya }\end{array}$ & $\begin{array}{l}\text { Pengaruh } \\
\text { industrialisasi } \\
\text { sangat kentara di } \\
\text { kawasan ini }\end{array}$ \\
$\begin{array}{l}\text { Arsitektur } \\
\text { Kebon Agung II }\end{array}$ & $\begin{array}{l}\text { kawasi di } \\
\text { urban peri- }\end{array}$ & $\begin{array}{l}\text { Perkembangan } \\
\text { kawasan peri- } \\
\text { urban di Malang } \\
\text { turut mendukung } \\
\text { perkembangan } \\
\text { arsitekturnya }\end{array}$ & $\begin{array}{l}\text { Meluasnya } \\
\text { dampak urban } \\
\text { dan industri } \\
\text { mengurangi } \\
\text { jumlah petani di } \\
\text { kawasan ini }\end{array}$ \\
\hline $\begin{array}{l}\text { Arsitektur } \\
\text { Kedawung } \\
\text { pasuruan }\end{array}$ & $\begin{array}{l}\text { Lokasi di } \\
\text { kawasan peri- } \\
\text { urban }\end{array}$ & $\begin{array}{l}\text { Manter kawasan } \\
\text { yangat turut } \\
\text { mewarnai } \\
\text { arsitekturnya }\end{array}$ & $\begin{array}{l}\text { dampak urban } \\
\text { dan industri } \\
\text { mengurangi } \\
\text { jumlah petani di } \\
\text { kawasan ini }\end{array}$ \\
\hline
\end{tabular}


Tabel 7. Pengelompokan Berdasarkan Arsitektonik

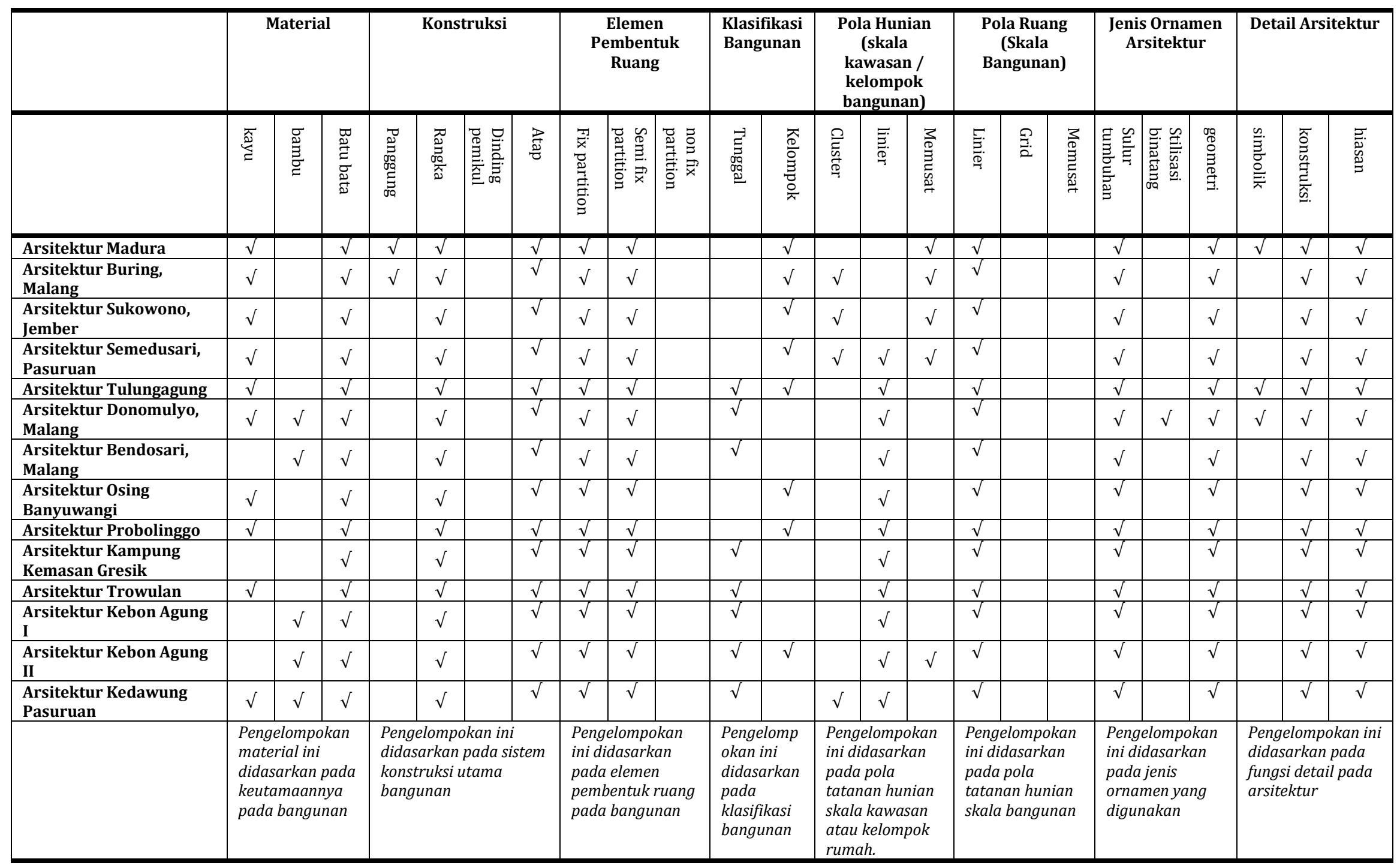


Tabel 8 Pengelompokan Berdasarkan Strategi Kebudayaan dan Nilai Luhur Nusantara

\begin{tabular}{|c|c|c|c|c|c|}
\hline & $\begin{array}{c}\text { Keperkasaan } \\
\text { Masyarakat } \\
\text { Megalit }\end{array}$ & $\begin{array}{c}\text { Kewaspadaan } \\
\text { Pelestari } \\
\text { Hutan }\end{array}$ & $\begin{array}{c}\begin{array}{c}\text { Ketekunan } \\
\text { dan }\end{array} \\
\text { Kebersamaan } \\
\text { Masyarakat } \\
\text { Tani } \\
\text { Pedalaman } \\
\end{array}$ & $\begin{array}{c}\text { Keterbukaan } \\
\text { Masyarakat } \\
\text { Pesisir }\end{array}$ & Visualisasi \\
\hline $\begin{array}{l}\text { Arsitektur } \\
\text { Madura }\end{array}$ & $\begin{array}{c}\text { Belum } \\
\text { teridentifikasi }\end{array}$ & $\begin{array}{c}\text { Belum } \\
\text { teridentifikasi }\end{array}$ & $\begin{array}{c}\text { Kebersamaan } \\
\text { terlihat pada } \\
\text { pola penataan } \\
\text { hunian }\end{array}$ & $\begin{array}{c}\text { Belum } \\
\text { teridentifikasi }\end{array}$ & \\
\hline $\begin{array}{l}\text { Arsitektur } \\
\text { Buring, Malang }\end{array}$ & $\begin{array}{c}\text { Belum } \\
\text { teridentifikasi }\end{array}$ & $\begin{array}{c}\text { Belum } \\
\text { teridentifikasi }\end{array}$ & $\begin{array}{c}\text { Kebersamaan } \\
\text { terlihat pada } \\
\text { pola penataan } \\
\text { hunian }\end{array}$ & $\begin{array}{c}\text { Belum } \\
\text { teridentifikasi }\end{array}$ & \\
\hline $\begin{array}{l}\text { Arsitektur } \\
\text { Sukowono, } \\
\text { Jember }\end{array}$ & $\begin{array}{c}\text { Belum } \\
\text { teridentifikasi }\end{array}$ & $\begin{array}{c}\text { Belum } \\
\text { teridentifikasi }\end{array}$ & $\begin{array}{c}\text { Kebersamaan } \\
\text { terlihat pada } \\
\text { pola penataan } \\
\text { hunian }\end{array}$ & $\begin{array}{c}\text { Belum } \\
\text { teridentifikasi }\end{array}$ & \\
\hline $\begin{array}{l}\text { Arsitektur } \\
\text { Semedusari, } \\
\text { Pasuruan }\end{array}$ & $\begin{array}{c}\text { Belum } \\
\text { teridentifikasi }\end{array}$ & $\begin{array}{c}\text { Belum } \\
\text { teridentifikasi }\end{array}$ & $\begin{array}{c}\text { Kebersamaan } \\
\text { terlihat pada } \\
\text { pola penataan } \\
\quad \text { hunian }\end{array}$ & $\begin{array}{c}\text { Kehidupan } \\
\text { masyarakat } \\
\text { pesisir } \\
\text { terlihat dari } \\
\text { dinamika } \\
\text { perubahan } \\
\text { arsitekturnya } \\
\end{array}$ & \\
\hline $\begin{array}{l}\text { Arsitektur } \\
\text { Tulungagung }\end{array}$ & $\begin{array}{c}\text { Belum } \\
\text { teridentifikasi }\end{array}$ & $\begin{array}{c}\text { Belum } \\
\text { teridentifikasi }\end{array}$ & $\begin{array}{c}\text { Kebersamaan } \\
\text { terlihat pada } \\
\text { pola penataan } \\
\text { hunian }\end{array}$ & $\begin{array}{c}\text { Belum } \\
\text { teridentifikasi }\end{array}$ & \\
\hline $\begin{array}{l}\text { Arsitektur } \\
\text { Donomulyo, } \\
\text { Malang }\end{array}$ & $\begin{array}{c}\text { Belum } \\
\text { teridentifikasi }\end{array}$ & $\begin{array}{c}\text { Belum } \\
\text { teridentifikasi }\end{array}$ & $\begin{array}{c}\text { Kebersamaan } \\
\text { terlihat pada } \\
\text { pola penataan } \\
\text { hunian }\end{array}$ & $\begin{array}{c}\text { Belum } \\
\text { teridentifikasi }\end{array}$ & \\
\hline $\begin{array}{l}\text { Arsitektur } \\
\text { Bendosari, } \\
\text { Malang }\end{array}$ & $\begin{array}{c}\text { Belum } \\
\text { teridentifikasi }\end{array}$ & $\begin{array}{c}\text { Belum } \\
\text { teridentifikasi }\end{array}$ & $\begin{array}{c}\text { Kebersamaan } \\
\text { terlihat pada } \\
\text { pola penataan } \\
\text { hunian }\end{array}$ & $\begin{array}{c}\text { Belum } \\
\text { teridentifikasi }\end{array}$ & \\
\hline $\begin{array}{l}\text { Arsitektur } \\
\text { Osing }\end{array}$ & $\begin{array}{c}\text { Belum } \\
\text { teridentifikasi }\end{array}$ & $\begin{array}{c}\text { Belum } \\
\text { teridentifikasi }\end{array}$ & $\begin{array}{c}\text { Kebersamaan } \\
\text { terlihat pada } \\
\text { pola penataan } \\
\text { hunian }\end{array}$ & $\begin{array}{c}\text { Belum } \\
\text { teridentifikasi }\end{array}$ & \\
\hline $\begin{array}{l}\text { Arsitektur } \\
\text { Probolinggo }\end{array}$ & $\begin{array}{c}\text { Belum } \\
\text { teridentifikasi }\end{array}$ & $\begin{array}{c}\text { Belum } \\
\text { teridentifikasi }\end{array}$ & $\begin{array}{c}\text { Belum } \\
\text { teridentifikasi }\end{array}$ & $\begin{array}{c}\text { Dominasi } \\
\text { ruang publik } \\
\text { sebagai ruang } \\
\text { bersama }\end{array}$ & 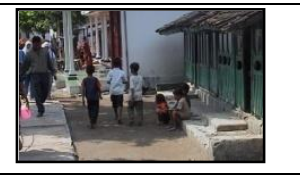 \\
\hline $\begin{array}{l}\text { Arsitektur } \\
\text { Kampung } \\
\text { Kemasan, } \\
\text { Gresik } \\
\end{array}$ & $\begin{array}{c}\text { Belum } \\
\text { teridentifikasi }\end{array}$ & $\begin{array}{c}\text { Belum } \\
\text { teridentifikasi }\end{array}$ & $\begin{array}{c}\text { Belum } \\
\text { teridentifikasi }\end{array}$ & $\begin{array}{c}\text { Keterbukaan } \\
\text { masyarakat } \\
\text { terlihat dari } \\
\text { beragam }\end{array}$ & \\
\hline
\end{tabular}




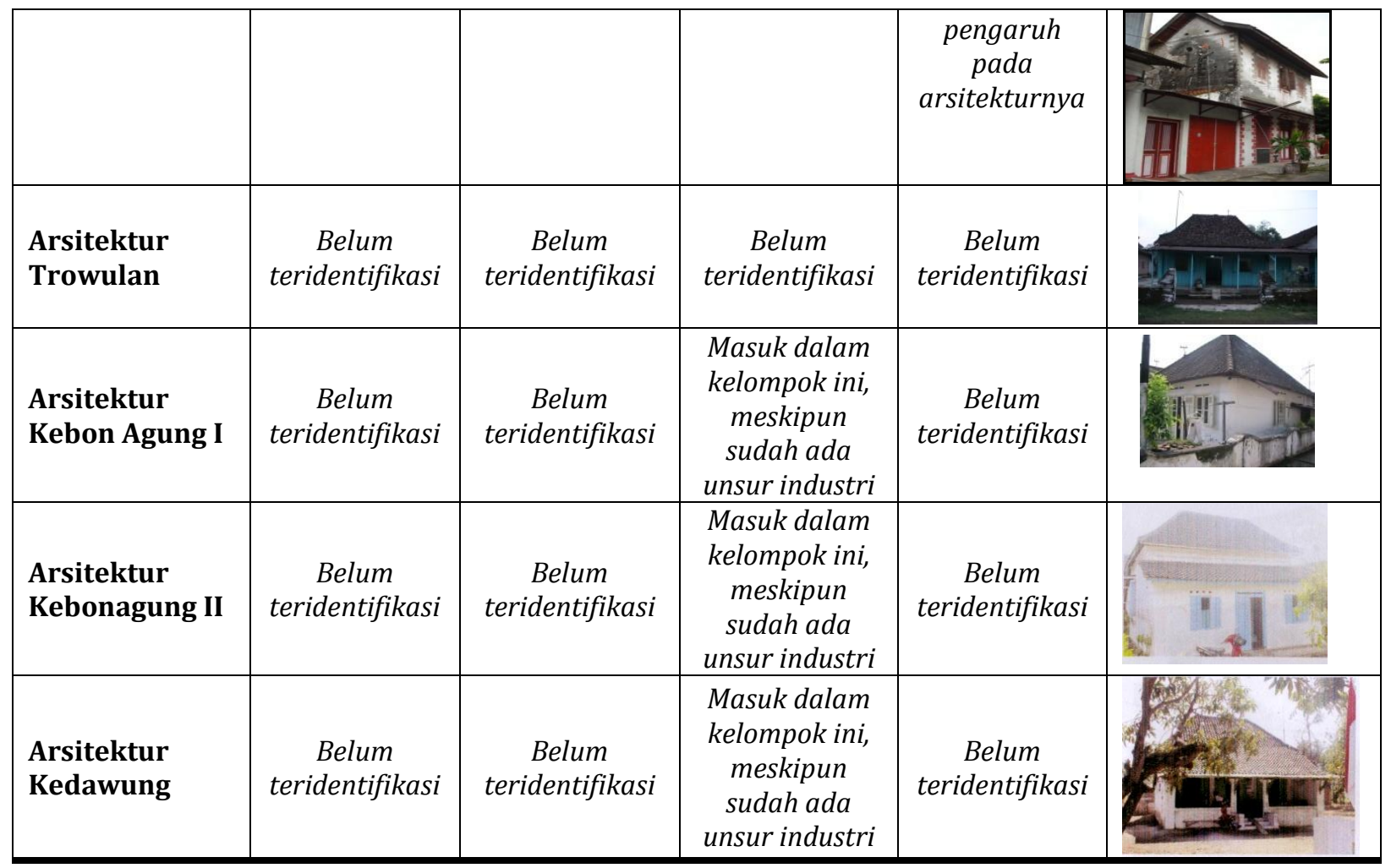

